\title{
GEOGLYPHS IN TIME AND SPACE
}

\author{
By \\ Jay von Werlhof*
}

\begin{abstract}
Using the relationship between art and religion as a take-off point, this article examines two types of earthen art: rock alignments and geoglyphs. Differences and similarities in form and content are discussed, as regarding earthen art in various locations, and speculations are made as regarding their religious significance.
\end{abstract}

\section{RESUMEN}

Partiendo de la relación entre el arte y la religión, este artículo examina dos tipos de arte construidos sobre la tierra misma: alineamiento de piedras y geoglifos. Aquí se. exponen brevemente las diferencias y semejanzas de forma y contenido de este arte en varias regiones y finalmente se proponen algunas teorías sobre su significado religioso.

As politics is ultimately rooted in economics, art is ultimately rooted in religion. Art underwent an explosion early in the evolutionary rise of Homo sapiens sapiens, who became particularly drawn to exploring graphically his awareness of spiritual forces and his place in the world they seemingly created. Seen as a cultural product to us, earthen art is part of the creative process toward which the primal mind turned (Pfeiffer, 1982; Highwater, 1981).

The evolution of earthen art roughly parallels other planary expressions that gradually moved from abstractions remote to human senses, to representations that graphically traced the awakening of man's ego, itself a creative force. The trend toward representationalism, however, never entirely displaced its older art form, whose ideologic content could not be portrayed in realistic plastic shapes, and hence remained veiled as imaginative and highly abstract icons.

Within the mode of earthen art there are two basic forms: rock alignments and geoglyphs. The rock alignment makes a positive image

\footnotetext{
* Imperial Valley Colley College Desert Museum.
} 
when rocks are arranged in a surface design. Geoglyphs make a negative image when surface pebbles are scraped away, forming a line on the denuded soil. Alignments are dependent upon the presence of a field of random boulders and cobbles for resources, while geoglyphs are dependent upon an open field of desert pavement. Since the two forms are made from different resources, they therefore rarely share the same plane (Hunt, 1960; Davis and Winslow, 1965; Brown, 1979; Johnson, 1985; von Werlhof, 1986; Ezzo and Altschul, 1993; Holmlund, 1993). Rock alignments alone, for example, comprise the current inventory of earthen art in the Australian cobbled deserts (Elkin, 1950; Berndt and Berndt, 1964). Similarly, on the rocky terrain of Panamint Valley in Inyo County, California, there are thirty-five reported rock alignments, and no geoglyphs (Davis and Winslow, 1965; von Werlhof, 1986; McCarthys, 1990). On the other hand, geoglyphs dominate the heavily concentrated fields of earthen art on the Peruvian Nazca Plains, where cobbles and boulders are scarce (Reiche, 1955, 1968a; Reinhard, 1987; Clarkson, 1990; Aveni, 1990). As an unusual variant, however, large stones are so profuse on the slopes of the Atacama Desert of Chile that alignments could not have been discernible, if made. Here, earthen artists removed boulders to make huge figural designs in geoglyph form on the rock-strewn surface (Morrison, 1978; Wilson, 1988; Casey unpublished mss 1990). On the Yuha Mesa in Imperial County, California, there are twenty-one geoglyphs scraped through the moderately paved desert surface, but no rock alignments (Casey unpublished mss, 1990; von Werlhof mss in preparation, 1994).

In Western North America, the earthen art field embraces portions of the Sonoran Desert and the Great Basin. Though still inconclusive, geologic dating (Davis, 1980) and one 14C date of a rock alignment of over 9000 years BP (Warren and Ore, 1978) indicate that this variety is the older of the two earthen art forms. Current studies in geoglyphs tend to support this hypothesis. An extensive field investigation still underway, will eventually settle the point. Eleven geoglyphs have now been processed with the cation-ratio AMS $14 \mathrm{C}$ method. The oldest glyph dated in this series is over 2700 years BP (see Table 1). Five more samples are currently being processed at Wood Hole laboratory.

My paper focuses on the temporal and spatial distribution - the when and the where- of geoglyphs. By now, the geoglyph population is virtually known for the Great Basin/Southwest study area. Until a scant years ago, numerous earthen art forms were annually reported through systematic ground and aerial surveys, as well as accidental discoveries. During this recent period there was one year in which none was reported at all. 
The principal investigators have been Boma Johnson, Bureau of Land Management archaeologist in Yuma, Arizona, Harry Casey, my co-worker who takes time, has dedication and airplanes, as well as a professional's gift in photography; and myself. The ranks have grown in the last few years, however, and include Dan McCarthy, Meg MacDonald, Jeffrey Altschul, Joseph Ezzo, James Holmlund, and Persis Clarkson, who is re-directing her field expertise from the deserts of Peru and Chile to include our Southwest.

So we know much of the "what" and the "where" of geoglyphs, but need to address more fully the other three questions of "who" formed them, and "when" and "why" were they prepared. Boma Johnson has laid the foundation for the "who" and the "why" through ethnographic research with Colorado River Tribes the Quechan and Mohave (Johnson, 1985). Ezzo and Altschul have recently expanded on one of Johnson's hypotheses linking Lower Colorado River geoglyphs with a Yuman keruk (mourning ceremony) trail and ceremonial rites. The authors have also tied warring activities, and possibly territorial markers, to these ground figures and features (Ezzo and Altschul, 1993). Holmlund also intensively investigated the Ripley site (AZ R:10:1), a.k.a. the Ripley Geoglyph Complex. Though he is more cautious with interpretations, he left precious little, if anything, to be discovered visually. Unlike most geoglyph sites, the Ripley complex includes several alignments of the cairn-assemblage type (Holmlund, 1993). Similar assemblages have been noted in direct association with alignments of the butted type (i.e., stones are butted together along a line), indicating that in some sites the assemblages were stockpiles whose stones were to be laid out on a linear scheme at some future time (von Werlhof fieldbook, 1992). The Ezzo and Altschul model oriented too site-specifally to explain most geoglyphs, which in all likelihood predate the keruk ceremony and the warring impulse of the Late Prehistoric or Protohistoric periods. In all probability, spiritual roles will eventually be assigned to the majority, if not all, of these intriguing designs.

A few similar, and some identical, designs tell us there was at least an ancillary connection between the iconography of rock art and earthen art. Aside from construction methods and planary surfaces, the most glaring difference between rock art and earthen art is that the former is universal, and the latter is severely regionated. Though the "why" of rock art is still largely unknown, it is becoming better understood in geoglyphy.

With earthen art, the "who" and the "when" are critically related to one, another since each prehistoric society of our study area underwent a major volkerwanderung during its Archaic Period, and remained quite mobile afterwards as part of adaptive strategies. In the Protohistoric Period 
warring was often mixed with trading and traveling (Davis, 1961; Forbes, 1965; White, 1974; Ezzo and Altschul, 1993; von Werlhof, 1994).

From ethnographic as well as archaeological evidence, it is clear that geoglyphs played an active cultural role in tribal life. According to Yuman (Kumeyaay, Mohave and Quechan) informants, such activity was conducted on ceremonial grounds already deemed sacred. These activities included: 1) Depiction and celebration of the creation myth. 2) Struggle with anti-social forces, such as Elder Brother in physical triumph over his evil twin. 3) The mythical past. 4) Keruk ceremony. 5) Initiation rites for boys, and possibly for girls. 6) Cultural renewal, with traditional singing and dancing. In addition to linear and circular dance patterns, there are also staging and monitoring areas, and "hopscotch" scars where jumping dances took place.

The ground figures emphasize the importance of Mother Earth as the source of fertility and power, as seen also in the natives' care and use of certain rock. They recognized quartz as the most energized of rocks (von Werlhof, 1968), and pulverized it to transfer its power to the person seeking the release (Millard, 1990). Fine-grained felsite was also reduced in power quests at ceremonial sites (von Werlhof, 1982).

As in rock art, the older geoglyph designs are non-representational lines or circles. Though these became traditional, forming a continuum from the past, earthen artists added pictorial elements in later years. The representational figures were mostly of the creator and his pantheon of icons, identified in Yuman stories as worm, thunderbird, spider, octopus, lizard, quail, lion, sheep, snake, scorpion, and fish. Sun, moon, Milky Way, water, arrows, and mountains also took place as permanent cadre against a world of threatening change. The sanctity of the designs and images remained inviolate, withstanding culture change as well as tribal enmity. Earthen art did not suffer the outrages that rock art had to bear through superimposition, defacement, and even destruction in prehistoric times.

All desert people underwent major migrations. The Yuman speakers apparently moved from central Baja California northward, where they gradually settled generalized territories as separate tribal units. The uninterrupted Yuman lands included northern Baja California, San Diego and Imperial counties, up the Colorado River to Needles, and eastward below the Grand Canyon and along the Gila River. The current focus of cultural history combines archaeological studies with reconstructed languages (Dyen, 1975; Fowler, 1983; Laylander, 1984; Mithun, 1990; Sutton, 1992; Pawley and Ross, 1993). Within that format, geoglyphs assume the centerpiece of this paper. Recent studies in glottochronology 
and lexicostatistics indicate that about 4000 B.C. the Yuman-Cochimi occupied a sector of north-central Baja California. By 3000 BC the Yuman had advanced to near the present International Border, and about 1000 B.C. the "core" Yuman had spread across what is now San Diego and Imperial counties. And by BC/AD the Yuman had moved upriver and eastward along the Gila River (Kendall, 1983; Laylander, 1984).

Something yet unexplained happened culturally during the migration. The Yuman bands which either had crossed the Peninsular Range from the inland deserts to the Pacific littoral, or had moved up the coast from Baja California, did not practice earthen art, but those that turned eastward onto the desert areas and terraces did.

$14 \mathrm{C}$ dates on geoglyphs at the base of the Peninsular mountains have been dated at 650 B.C., corresponding to the core Yuman dates that glottochronology provide us. Did the Yuman bring geoglyphy as traditional baggage from their Baja California base? They claim to have been created in their now traditional territories, possibly indicating that earthen art was formed in celebration of that accepted event. A people's embracement of a new country (von Franz, 1970; Bowlby, 1982) has seldom been more complete even after such a slow-paced migration. The creation myths and geoglyph construction of the Yuman tribes center on their adopted lands (Kroeber, 1925; Forde, 1931; Luomala, 1978; Cline, 1979; Alvarez de Williams, 1983; Stewart, 1983; Johnson, 1985; Ezzo and Altschul, 1993).

The process for geoglyph cation-ratio AMS 14C dating (Dorn, 1991) is complex and still controversial to many scientists. The patterned results, however, have not violated common sense or suppositions of archaeological age. When geoglyphs are formed, lichen begins to grow on the exposed rock which desert varnish eventually encapsulates. The subsequent decay of the organism sets off the radiocarbon clock. The critical point is removing the micro-organic remains for the $14 \mathrm{C}$ dating process. The Table 1 shows eleven dates from sixteen samples sent to Wood Hole Laboratory for processing. The dates shown are BP (Before Present), and do not show the plus/minus factor. The plus/minus spread varied from 25 to 60 years for the group of samples.

Four additional geoglyphs are slated for field sampling this fall. These are being selected to provide a wide spread in geographic location as wel] as suspected age. So far, the Radiocarbon dates suggest that these ceremonial sites were developed and used over long periods of time, witt elements gradually being added to the core design. This further suggest: that the process of glyph making was as important as, and maybe mon important than, the product. Together, these points indicate that growtl 
Table 1.14C Dated Geoglyphs.

\begin{tabular}{lll}
\hline 1) Schneider Dance Circle & 2790 & 4-Imp-2491 \\
2) Ocotillo Museum Site & 2640 & 4-Imp-3045 \\
3) Singer Site, Pilot Knob Mesa & 1600 & 4-Imp-4978 \\
4) Lizard Figure, Ripley Complex & 1560 & AZ-R:10:1 \\
5) Anthropomorph, Quartzite Airport & 1540 & AZ: \\
6) Amorphous, Quartzite Airport & 1480 & $\mathrm{AZ:}$ \\
7) Anthropomorph \#2, " " & 1380 & $\mathrm{AZ}:$ \\
8) Anthropomorph " " & 1260 & $\mathrm{AZ:}$ \\
9) Blythe Giant \#1 & 1100 & 4-Riv- \\
10) Anthropomorph, Pilot Knob & 945 & 4-Imp-5224 \\
11) Winterhaven, Kumastamho & 840 & 4-Imp-2990 \\
& & \\
\hline
\end{tabular}

Note: Samples Collected by Dr. Ronald Dorn and Dr. Persis Clarkson, 1993.

and continuity are essential partners in the making of traditions which, themselves, are vital to the preservation of a culture.

The interfacing study of geochronology and cation-ratio $14 \mathrm{C}$ dating programs poses the prospect of revising the developmental line of Yuman traditions and Yuman cultural history. While some scholarly circles raise unanswered questions about both studies, we might ponder the reply a Mohave elder gave to a doubting interrogator about his religion: "If I can't answer your question, maybe something is wrong with the question". 


\section{BIBLIOGRAPHY}

ALVAREZ de Williams, Anita. 1974. The Cocopah People. Indian Tribal Series, Phoenix, Arizona.

AVENI, Anthony (ed.). 1990. The Lines of Nazca. American Philosophical Society, Philadelphia.

BEE, Robert. 1983. "The Quechan" in Alfonso Ortiz, ed., Handbook of The North American Indians, vol. 10. Smithsonian Institution, Washington, D.C.

BERNDT, R. and C. Berndt. 1964. The World of the First Australians. Sydney, Australia.

BOWLBY, John. 1982. "Attachment and Loss: Retrospect and Prospect". American Journal of Orthopsychiatry, vol. 52:4, 664-678.

BROWN, Robert. 1979. "Bock's Puzzle”, in Archaeological Survey Association Journal, vol. 3:2.

CASEY, Harry. 1990. Unpublished mss, private library.

CASTETTER, Edmund and Willis Bell. 1951. Yuman Indian Agriculture. University of New Mexico, Albuquerque, New Mexico.

CLARKSON, Persis. 1990. "Archaeology of the Nazca Pampa, Peru: Environmental and Cultural Parameters", in Lines of Nazca, Anthony Aveni, ed. American Philosophical Society, Philadelphia, Pennsylvania.

CLINE, Lora. 1979. Reflections on a Lost Culture. Imperial Valley College Museum, El Centro, California.

DAVIS, Emma Lou, Kathyrn Brown, Jacqueline Nichols. 1980. "Evaluation of Early Human Activities and Remains in the California Desert," Cultural Resources Publications: Anthropology-History, Eric Ritter, ed. Bureau of Land Management, Riverside, California.

DAVIS, Emma Lou and Sylvia Winslow. 1965. "Giant Ground Figures of the Prehistoric Deserts", Proceedings of the American Philosophical Society Yearbook, vol. 104:1. American Philosophical Society, Philadelphia, Pennsylvania.

DAVIS, James. 1961. "Trade Routes and Economic Exchange Among the Indians of California", University of California Archaeological Survey Report No.54. University of California, Berkeley, California.

DORN, Ronald. 1991. "Rock Varnish", American Scientist, Nov/Dec 1991, vol. 79:542-553. 
DYEN, Isidore. 1975. Linguistic Subgrouping and Lexicostatistics. Marton, The Hague, Netherlands.

ELKIN, P.A. 1950. "Religion of Australian Aborigines", in Vergilus Ferm, ed., Ancient Religions. Cita del Press, New York.

FORBES, Jack. 1965. Warriors of the Colorado. University of Oklahoma Press, Norman, Oklahoma.

FORDE, C. Daryl. 1931. "Ethnology of the Yuman Indians", University of California Publications in American Archaeology and Ethnology, 28(4): 83-278.

FOWLER, Catherine. 1983. "Some Lexical Clues to Uto-Aztecan Prehistory", International Journal of American Linguistics, 49:224-257.

HAYDEN, Julian. 1976. "Pre-Altathermal Archaeology in the Sierra Pinacate, Sonora, Mexico", American Antiquity, 41: 274-289.

HIGHWATER, Jamake. 1981. The Primal Mind in Vision and Reality in the American Indian. Houghton Mifflin, New York, New York.

HOLMLUND, James. 1993. The Ripley Geoglyph Complex: Results of an Intensive Survey. Statistical Research, Technical Report No. 9315. Tucson, Arizona.

HUNT, Alice. 1960. "Archaeology of the Death Valley Salt Pan, California", Archaeology Paper 47, October 1960. University of Utah, Salt Lake City, Utah.

JOHNSON, Boma. 1985. Earth Figures of the Lower Colorado and Gila River Deserts: A Functional Analysis. Arizona Archaeological Society, Phoenix, Arizona.

KENDALL, Martha. 1983. "Yuman Languages", in Alfonso Ortiz, ed., Handbook of North American Indians, vol. 10, Smithsonian Institution, Washington, D.C.

KROEBER, A.L. 1925. Handbook of Indians of Califormia. Smithsonian Institution, Washington, D.C.

LAYLANDER, Don. 1984. "Some Linguistic Approaches to Southern California Prehistory", Casual Papers, Cultural Resources Management Center, San Diego State University, July 1985, vol. 2:1, 14-58.

LUOMALA, Katherine. 1978. "Tipai and Ipai", in R.F. Heizer, d., Handbook of North American Indians, vol. 8. Smithsonian Institution, Washington, D.C.

MILLARD, Arnold. 1990. Personal Communication, Quechan Elder.

MITHUN, Marianne. 1990. "Studies of North American Indian Languages", Annual Review of Anthropology, Bernard Siegel, ed. Vol. 19:309-30. 
MORRISON, T. 1978. The Mystery of the Nazca Lines. Nonesuch, Suffolk, England.

PAWLEY, Andrew and Malcolm Ross. 1993. "Austronesian Historical Linguistics and Culture History", Annual Review of Anthropology, William Durham, ed. Vol. 22:425-459.

PFEIFFER, John. 1982. The Creative Explosion. Harper and Brothers, New York, New York.

REICHE, Maria. 1955. Prehistoric Ground Drawings in Peru. Photographie und Forschung 6 (4). Stuttgart, Germany.

- 1968. Giant Ground Drawings on the Peruvian Desert. International Congress of Americanists. Stuttgart, Germany.

SUTTON, Mark. 1992. "The Numic Expansion as Seen from the Mojave Desert", Kelso Converence on Mojave Desert Prehistory, Joshua Tree National Monument, 14 Nov. 1992.

VON FRANZ, Marie-Louise. 1970. Patterns of Creativity Mirrored in Creation Myths. Spring Publications, Zurich, Switzerland.

VON WERLHOF, Jay. 1982. Investigations of the Big Maria Mountains Archaeological District, with Appended Ethnographic Reports by John Lowell Bean and Sylvia Brakke Vane, and Mohave Archaeologist Weldon Johnson. Imperial Valley College Museum, El Centro, California.

- 1986. "The Rock in Rock Art", in Ken Hedges, ed., Rock Ari Symposium Papers, vol.4. San Diego Museum of Man, San Diego, California.

- 1989. Spirits of the Earth, vol.1. Imperial Valley College Museum, El Centro, California.

- 1994. "A Yuman Geoglyph Along the Lower Mojave River?", Kelso Conference Papers, 1:1. California State University Bakersfield, Bakersfield, California.

WARREN, Claude N. and James Ore. 1978. "Approach and Process of Dating Lake Mohave Artifacts". Journal of California Anthropology, (2) 179-187.

WHITE, Christopher. 1974. "Lower Colorado River Aboriginal Warfare and Allied Dynamics", in Antap: California Political and Economic Organization, John Lowell Bean and Thomas King, eds. Ballena Press, Ramona, California.

WILSON, D. 1988. "Desert Ground Drawings in the Lower Santa Valleys, Northern Coast of Peru". American Antiquity, 53 (4) 794- 804. 